\title{
A New Jatropha curcas Variety (JO S2) with Improved Seed Productivity
}

\section{Chengxin Yi ${ }^{1}$, Chalapathy Reddy ${ }^{1}$, Kins Varghese ${ }^{1}$, Thi Ngoc Ha Bui ${ }^{2}$, Shilu Zhang ${ }^{1}$, Manju Kallath ${ }^{1}$, Binoy Kunjachen ${ }^{1}$, Srinivasan Ramachandran ${ }^{1,2}$ and Yan Hong ${ }^{1, *}$}

1 JOil (S) Pte Ltd, 1 Research Link, National University of Singapore, Singapore 117604, Singapore; E-Mails: chengxin@joil.com.sg (C.Y.); reddy@joil.com.sg (C.R.); kins@joil.co.in (K.V.); shilu@joil.com.sg (S.Z.); manjukallath@gmail.com (M.K.); binoy@joil.co.in (B.K.)

2 Temasek Life Sciences Laboratory, 1 Research Link, National University of Singapore, Singapore 117604, Singapore; E-Mails: ngocha25@yahoo.com (H.B.); sri@tll.org.sg (S.R.)

* Author to whom correspondence should be addressed; E-Mail: hongy@joil.com.sg; Tel.: +65-68-729-803; Fax: +65-68-729-891.

Received: 20 March 2014; in revised form: 25 June 2014 / Accepted: 4 July 2014 / Published: 16 July 2014

\begin{abstract}
One key reason for the failure of Jatropha plantation is the use of non-improved planting materials. We present in this paper a Jatropha variety (JO S2) through selective breeding with much better seed productivity than wild accessions as proven by field trials in Singapore and India. In a single farm trial in Singapore for two years, a comparison was conducted with accessions from China, India, Indonesia and Africa. It was found that all traits studied like seed yield, seed kernel content, seed oil content, fatty acid composition, phosphorus content and PE content differed significantly among and within the wild accessions. Overall, JO S2 was the best performer with the highest seed yield, high oil content and low phosphorus content. On two sites in Tamil Nadu, Southern India, this Jatropha variety produced up to 2.95 ton/ha of dry seeds in the first year and up to 4.25 ton/ha of dry seeds in the second year, much better than the local variety control. We attribute its higher seed productivity to early flowering, better self-branching, more flower/fruiting bunches, more fruits per bunch and importantly, better uniformity among plants. This exemplifies that breeding has improved Jatropha seed productivity which will lead to better economics for Jatropha plantation.
\end{abstract}

Keywords: Jatropha curcas; breeding; improved Jatropha varieties; field trial 


\section{Introduction}

Jatropha curcas L. (physic nut, J. curcas, a member of the Euphorbiaceae family) is a drought tolerant shrub widely distributed in tropical and subtropical regions. It is an oil bearing plant (the seed contains up to $40 \%$ of oil) that is able to adapt to diverse eco-geographical environments. It has been used as a multi-functional plant for traditional medicine, bio-pesticide, land erosion control, live hedge, oil for lighting and soap making. Recently J. curcas has been promoted as a feedstock plant for biodiesel and bio jet fuel for its high oil quality and adaptability to dry and non-productive land [1,2]. $J$. curcas, however, is a non-domesticated plant. Commercial viability of Jatropha plantation depends on predictable good seed/oil productivity. Experts from different countries agreed that a seed yield of 4-5 tons would be necessary for its commercial viability [3]. Without much scientific agronomical study, there were many assumptions and anticipations that the yield of Jatropha varies from $0.2 \mathrm{~kg}$ to $>2 \mathrm{~kg}$ seeds from a single plant or 2 to $5 \mathrm{tha}^{-1}$ and even 7.8 to $12 \mathrm{t} \mathrm{ha}^{-1}$ [4]. Optimistic but non-verified expectations were behind many Jatropha plantation projects that failed [4,5]. When Jatropha was put to scientific tests under various climate conditions and agronomic practices, seed yield from wild accessions fell short of expectations. The average seed yield obtained in Senegal was at best $500 \mathrm{~kg} \mathrm{ha}^{-1}$ after four years of cultivation using drip irrigation and best available practices [6], much less than $5.25 \mathrm{t} \mathrm{ha}^{-1}$ expected. In South Africa [7], the best yield for four year old mono-cropped Jatropha plants was only $349 \mathrm{~kg} \mathrm{ha}^{-1}$. In another trial conducted in Haryana, India for three years, under irrigation and fertilization, Jatropha seed yield reached $473 \mathrm{~kg} \mathrm{ha}^{-1}$ [8]. A progeny trial of 32 plus trees collected from Andhra Pradesh, India found significant differences in plant height, seed productivity, seed morphology and oil content among the 34 month old progenies with seed productivity ranged from 34 to $263 \mathrm{~g} \mathrm{plant}^{-1}$ at spacing of $3 \mathrm{~m} \times 3 \mathrm{~m}$ [9]. Recently, a seven site, multiple factor (spacing, pruning and irrigation and fertilizer) field trial [10] of an elite Jatropha accession in India was reported. The best seed productivity achieved was $1,440 \mathrm{~kg} \mathrm{ha}^{-1}$ (at spacing of $2 \mathrm{~m} \times 2 \mathrm{~m}$ ) for five year old plants. Jatropha plants in these trials all failed to reach the 4-5 t seed productivity threshold for commercial viability. Less than satisfactory outcomes for wild Jatropha accessions underline the urgent need for improvement through systematic breeding.

In addition to low and variable seed productivity, seed traits of Jatropha also vary. One study assessed [11] the variability in the seed traits and oil content of 24 accessions of $J$. curcas collected from different agro climatic zones of Haryana state, India and revealed that there were significant differences in seed size, 100-seed weight and oil content among accessions. In a similar study on 72 $J$. curcas accessions representing 13 countries, biochemical composition analysis of seeds showed wide variation in seed kernel crude protein, oil content, ash content and phorbol ester (PE) in seed [12]. Similarly, a two year progeny field trial conducted in Singapore with accessions from India, Indonesia, China, Africa and South America found significant variability in 1 year and 2 year accumulated seed yield, plant height at 2 year, number of primary branches, number of flowering branches, dormancy during drought period, time from seed sowing to first flowering as well as seed oil content [13]. For commercial plantation, there is the urgent need for improvement towards higher seed productivity and better uniformity in field.

Another constraint in the widespread acceptance of $J$. curcas is the presence of anti-nutrient factors in seeds such as phytate, curcins, saponin and the co-carcinogenic phorbol esters [14]. A wide range of 
PE content has been reported in natural $J$. curcas accessions $[15,16]$. On the other hand, $J$. curcas oil phosphorus content is higher than those in rapeseed oil and palm oil. Phosphorus derived from phytate and phospholipids in crude oil leads to the formation of gum during oil production; hence increasing biodiesel production cost [17].

We have conducted systematic breeding since 2006. Initial intensive evaluations of accessions on an individual plant basis were followed by putting selected plus plants (mainly based on seed productivity) together for harvesting their open pollinated seeds. This process was repeated twice until a more uniform seed derived population with better seed productivity was achieved. One such new variety JO S2 was first put through random block design single farm field trial for two years in Singapore in comparison with four distinct $J$. curcas accessions from China, Indonesia, India and Africa, all grown in the same farm under common agronomic practices. Accumulated seed yield and various seed quality traits were analyzed and compared among populations. Subsequent to this single farm, single climate (hot, humid) trial, we conducted trials in two sites in Southern India (generally very dry and hot). We aim to access improvements to $J$. curcas after systemic breeding and checking if the good performance of an improved variety could be repeated in a bigger area under different agro-climate conditions.

\section{Experimental Section}

\subsection{Breeding History}

JO S2 was originated from an open pollinated seed population (GN) harvested from plus trees of accessions from Malaysia and Thailand. Systematic mass selections were conducted from the initial GN population in Singapore. Plus plants with vigorous growth, early flowering, natural branching, better productivity and a better oil profile were selected for seed harvest. Open pollinated seeds from multiple plus trees were harvested and mixed together to form the original breeder seeds of JO S2, which were used for a small field trial firstly in Singapore for two years followed by multi-location field trials in the Tamil Nadu state of Southern India.

The KE population was derived from seeds harvested from plus trees in one accession of Indonesia (MD) planted in Singapore.

\subsection{Plant Materials and Field Trial}

Accessions collected in the form of seeds from $J$. curcas trees in Tanzania $\left(1^{\circ} 59^{\prime}\right.$ to $2^{\circ} 30^{\prime} \mathrm{S}$, and $32^{\circ} 10^{\prime}$ to $33^{\circ} 50^{\prime} \mathrm{E}$ ) Africa (AF); Yunnan Province ( $21^{\circ} 27^{\prime}$ to $22^{\circ} 36^{\prime} \mathrm{N}$, and $100^{\circ} 25^{\prime}$ to $101^{\circ} 31^{\prime} \mathrm{E}$ ), China $(\mathrm{CN})$ and Tamil Nadu $\left(10^{\circ} 10^{\prime}\right.$ to $11^{\circ} 30^{\prime} \mathrm{N}$, and $76^{\circ} 40^{\prime}$ to $\left.78^{\circ} 50^{\prime} \mathrm{E}\right)$, India (TN), improved population derived from accession of Maluku Island $\left(3^{\circ} 03^{\prime} \mathrm{S}\right.$, and $\left.130^{\circ} 8^{\prime} \mathrm{E}\right)$, Indonesia (KE), and the improved variety (JO S2) developed in Singapore were arranged in a field trial in Singapore. The site had red heavy clay soil and annual average precipitation was around $2500 \mathrm{~mm}$. Seeds were germinated in March 2008 and seedlings were transplanted in May 2008 into pits of $1 \mathrm{~m} \times 1 \mathrm{~m} \times 1 \mathrm{~m}$ filled with top soil with space of $2 \mathrm{~m} \times 2 \mathrm{~m}$ for each tree on the farm of Temasek Life sciences Laboratory (TLL), Singapore $\left(1^{\circ} 26^{\prime} \mathrm{N}\right.$, and $\left.103^{\circ} 42^{\prime} \mathrm{E}\right)$. The field management, such as fertilization, pesticide spraying and weed controlling, followed the general practices, and only one or two irrigations were provided during 
the dry spell. Mature fruits (yellow or black) were collected from each individual tree, dehusked, dried in the shade, and their seeds weighed. Seeds harvested for each plant from October 2008 to January 2009 were pooled and subjected to seed traits and oil characteristic analysis.

\subsection{Total Crude Fat Content}

Seed crude fat (oil) content was determined by following the American Oil Chemist Society (AOCS) Official Procedure Am 5-04 by the ANKOM Extraction System (Ankom, Macedon, USA) with hexane as the solvent, with three replicates for each seed sample.

\subsection{Oil Extraction}

$J$. curcas crude oil (JCO) was extracted from dried kernels by the accelerated solvent extraction system ASE200 (Dionex, Sunny vale, USA) with hexane alone or hexane followed by ethyl acetate and dried by nitrogen stream at $45{ }^{\circ} \mathrm{C}$. The oil extracted with hexane was used for fatty acid profile determination. The oil extracted with hexane followed by ethyl acetate was used for the analysis of Phosphorus and PE content.

\subsection{Fatty Acid Profile Determination}

The SUPLECO methyl esterification kit (Sigma) was used to convert JCO to fatty acid methyl esters (FAME). The composition of the FAMEs was determined by gas chromatography (Agilent GC 6890 ) with a DB-23 $30 \mathrm{~m} \times 0.25 \mathrm{~mm}$ capillary column. The GC condition was set up as a helium carrier gas flow rate of $20 \mathrm{~cm} / \mathrm{s}$; the oven temperature ramped from $140{ }^{\circ} \mathrm{C}(5 \mathrm{~min})$ to $240{ }^{\circ} \mathrm{C}$ $\left(4{ }^{\circ} \mathrm{C} / \mathrm{min}\right.$ ); The Flame ionizing detector (FID) was at $280^{\circ} \mathrm{C}$. Palmitic acid, Stearic acid, Oleic acid and Linoleic acid compositions were qualified in reference to standard FAMEs (Sigma) and quantified by the percentage of peak area. Each seed sample was analyzed three times.

\subsection{Phorbol Ester Determination [18]}

Two to three grams of ground kernel were extracted with n-hexane, followed by Ethyl acetate, to ensure the complete extraction of PE. The extracted oil was quantified for PEs by a Symetry C18, $5 \mu \mathrm{m}, 4.6 \times 250 \mathrm{~mm}$ HPLC column (Waters, Milford, USA) with an Agilent 1200 HPLC system in reference to a standard curve of reference phorbol myristic acetate (PMA, Sigma). Mobile phase of water (A) and methanol plus $1 \%$ acetic acid (B) was applied. PEs were eluted by a gradient of $60-80 \%$ B (25 min), 80-85\% B (15 min) then held at 95\% B (10 min). The 5 peaks between 31 and $35 \mathrm{~min}$ detected at $280 \mathrm{~nm}$ by Diode-array detector (DAD) were quantified as total PE in reference to the external PMA standard, which appeared at 33.5-34 min. Each seed sample was analyzed three times.

\subsection{Phosphorus Evaluation}

JCO was baked inside a furnace at $600{ }^{\circ} \mathrm{C}$ for $2 \mathrm{hr}$. Inorganic phosphorus in JCO was quantified by following phosphorus determination method Ca 12-55 (1997) of American Oil Chemical Society. Each seed sample was analyzed three times. 


\subsection{Cetane Number Prediction}

Cetane number was predicted by the formula below: [19]

$$
\begin{gathered}
\text { Cetane number }=61.1+0.088 *(\% \mathrm{C} 14: 0)+0.1338 *(\% \mathrm{C} 16: 0)+0.152 *(\% \mathrm{C} 18: 0)-0.101 * \\
(\% \mathrm{C} 16: 1)-0.039 *(\% \mathrm{C} 18: 1)-0.243 *(\% \mathrm{C} 18: 2)-0.395 *(\% \mathrm{C} 18: 3)
\end{gathered}
$$

\subsection{CFPP Prediction}

The CFPP (cold filter plugging point) is the temperature at which fuel will plug a fuel filter. CFPP was predicted by the formula below [20]:

$$
\mathrm{CFPP}=3.1417 * \mathrm{LCSF}-16.477
$$

Long chain saturated factor $(\mathrm{LCSF})=0.1 \mathrm{C} 16: 0(\mathrm{wt} \%)+0.5 \mathrm{C} 18: 0(\mathrm{wt} \%)$

\subsection{Data Analysis}

The data of quality traits and phytochemical properties was recorded as the mean value of three replicates for each sample. Seed trait variation among populations was evaluated via ANOVA analysis and Tukey comparison through XLSTAT software 7.5.2 (Addinsoft, New York, USA). The coefficient of variance $(\mathrm{CV})$ was determined as the ratio of standard deviation to the mean.

\subsection{India Field Trial Details}

JO S2 plants were planted in two locations (1 acre each site) in Tamil Nadu state in the South of India. One site was near Coimbatore $\left(11^{\circ} 18^{\prime} \mathrm{N}, 76^{\circ} 57^{\prime} \mathrm{E}\right)$ and another site was near Madurai $\left(9^{\circ} 55^{\prime} \mathrm{N}\right.$, $78^{\circ} 7^{\prime} \mathrm{E}$ ), which is $180 \mathrm{~km}$ from Coimbatore. Annual average rainfall of these regions is 600 to $650 \mathrm{~mm}$, with temperature ranges between 20 to $35^{\circ} \mathrm{C}$ at an altitude of 300 to 350 above sea level. Soil in Madurai site is red sandy loam with $\mathrm{pH} 7.8$ whereas soil in Coimbatore site is sandy gravel with $\mathrm{pH}$ 6.9. More than half of annual rainfall happens in September, October and November.

The field trial plots were prepared by ploughing and clearing all the weeds. Two month old seedlings were transplanted into pits $(30 \mathrm{~cm} \times 30 \mathrm{~cm} \times 30 \mathrm{~cm})$ at $2 \mathrm{~m} \times 2 \mathrm{~m}$ spacing and, in which mycorrhiza was applied during transplanting. One month later plants were given manure $(1 \mathrm{~kg}$ per plant) and further fertilization was conducted based on needs. The fields were maintained free from weeds throughout the trial period; and pesticides and fungicides were sprayed when necessary. It was observed that mealybug, broad mite, leaf webber, and shoot borer were the most commonly found pests and powdery mildew was commonly occurred during cooler seasons of the year. Plants were irrigated during dry spells. Yellow/black fruits are harvested manually, dehusked, air dried and weighed. For data collection plants, seeds were harvested and processed on single tree basis.

In Coimbatore site, a commonly planted Indian variety was planted as the control population. For each site, 25 (Coimbatore) or 50 (Madurai) randomly plants were chosen and labelled at time of transplanting for comprehensive data collection (data collection plants). Important agronomic traits, such as plant height, canopy, number of primary branches, number of flower bunches, number of fruit bunches, number of fruits per bunch, number of fruits per plant and seed harvested on individual plant, 
were collected from data collection plants monthly from third month after transplanting onwards. Seeds were collected at the end of second year for crude oil content analysis.

\section{Results and Discussion}

\subsection{Diversity of J. curcas Seed Productivity and Seed Quality Traits}

Consistent with the opinion that the domestication of $J$. curcas has not been completed and that its yield is difficult to predict with accuracy [16], we discovered a wide range of variation in seed productivity, both among and within populations (Table 1) especially for wild accessions in Singapore trial.

Table 1. Diversity in seed yield and seed characteristics among $J$. curcas populations in the first year in Singapore.

\begin{tabular}{|c|c|c|c|c|c|c|c|c|c|c|}
\hline \multirow{2}{*}{$\begin{array}{c}\text { Populations } \\
\text { (n) }\end{array}$} & \multicolumn{2}{|c|}{ Seed Yield/Plant (g) } & \multicolumn{2}{|c|}{$\begin{array}{c}\text { 100-Seed Weight } \\
\text { (g) }\end{array}$} & \multicolumn{2}{|c|}{$\begin{array}{c}\text { Crude Fat/Kernel } \\
(\%)\end{array}$} & \multicolumn{2}{|c|}{ Kernel/Seed (\%) } & \multicolumn{2}{|c|}{$\begin{array}{c}\text { Crude Fat/Seed } \\
(\%)\end{array}$} \\
\hline & Mean & CV (\%) & Mean & CV (\%) & Mean & CV (\%) & Mean & $\begin{array}{l}\text { CV } \\
(\%)\end{array}$ & Mean & $\begin{array}{l}\text { CV } \\
(\%)\end{array}$ \\
\hline $\mathrm{AF}(120)$ & $333.6^{b}$ & 20.2 & $72.6^{\mathrm{a}}$ & 4.3 & $48.7^{\mathrm{a}}$ & 10.5 & $62.0^{\mathrm{ab}}$ & 2.5 & $30.2^{\mathrm{a}}$ & 11.6 \\
\hline $\mathrm{CN}(120)$ & $22.0^{\mathrm{c}}$ & 83.9 & $73.8^{a}$ & 9.7 & $43.9^{c}$ & 7 & $61.3^{b c}$ & 3.9 & $26.9^{c}$ & 8.8 \\
\hline JO S2 (24) & $658.8^{a}$ & 41.6 & $65.4^{\mathrm{c}}$ & 7.7 & $45.9^{b}$ & 6.4 & $62.8^{\mathrm{a}}$ & 3.1 & $28.8^{b}$ & 6.8 \\
\hline KE (180) & $415.7^{b}$ & 43.9 & $65.7^{\mathrm{bc}}$ & 6.9 & $45.3^{\mathrm{bc}}$ & 8.5 & $60.7^{\mathrm{c}}$ & 3.4 & $27.5^{\mathrm{c}}$ & 8.8 \\
\hline $\mathrm{TN}(75)$ & $25.9^{c}$ & 76.1 & $68.3^{b}$ & 13.6 & $45.1^{\mathrm{bc}}$ & 8 & $60.4^{c}$ & 4 & $27.3^{c}$ & 9.9 \\
\hline
\end{tabular}

Populations were from Africa (AF), China (CN), Tamil Nadu, India (TN), Indonesia (KE) and the improved variety, JO S2; CV (\%), coefficient of variance (\%); Tukey's (HSD) comparison ranking $(p<0.05)$ : $\mathrm{a}>\mathrm{b}>\mathrm{c}$.

The improved population (JO S2) showed the highest accumulative seed yield $\left(658.8 \mathrm{~g} \mathrm{plant}^{-1}\right)$ in the first year. This seed yield is equivalent to $1.65 \mathrm{tha}^{-1}$ with $2 \mathrm{~m} \times 2 \mathrm{~m}$ spacing between trees (a density of 2500 trees per hectare). The second highest yield was observed for the improved material from Indonesia accession (KE), followed by the African accession (AF). The India accession (TN) and Chinese accession $(\mathrm{CN})$ performed the most poorly. Besides statistically significant differences among populations, variations within the respective populations were noticeable by the disparity between the minimum and the maximum seed yield and high CV values. JO S2, KE and AF populations exhibited lower variation in accumulative seed yield (CV ranges from 20.2 to $43.9 \%$ ) whereas $\mathrm{TN}$ and $\mathrm{CN}$ populations had high level of variation ( $\mathrm{CV}$ values of $76.1 \%$ and $83.9 \%$ respectively). For the second year seed yield, JO S2 achieved $987.8 \mathrm{~g} \mathrm{plant}^{-1}$ or $2.47 \mathrm{t} \mathrm{ha}^{-1}$ and remains the best performer.

Hundred seed weight (W100) is a good evaluation of seed size. It was also found to vary greatly, from 30 to $93 \mathrm{~g}$ among individual plants. The Chinese (CN) and African (AF) populations produced the heaviest seeds, while the lowest variation was observed in the AF population.

Apart from seed yield, seed oil content also contributes to total oil productivity. Oil content can be further divided into two contributing factors: kernel content in seed and crude fat content in kernel. Tukey's (HSD) comparison revealed difference in all the three traits in the 5 populations. At individual plant level, a big variation in seed oil content (17 to 38\%) was found. The highest average kernel content (62.8\%) per seed was found for JO S2 population, while the AF population had the highest kernel crude fat content (48.7\%) and seed crude fat content $(30.2 \%)$. 
Besides variations among the populations, there was also within-population variation, represented by $\mathrm{CV}(\%)$ values. Compared to seed yield, seed quality traits in general had a lower level of variation within population. With the lowest CV values, kernel content in seed is found to be mostly consistent in every population.

From the trial in Singapore (Table 1), it was found that improved populations (JO S2 and KE) gave higher accumulated seed yield, had moderate crude fat content, relatively lower variation within population (all five traits' CVs of JO S2 and KE were lower than that of non-improved accessions except seed yield/plant and 100-seed weight of AF). These results demonstrate that the improved populations are better in per plant seed yield as well as uniformity. Between the two improved populations, JO S2 performed significantly better in higher seed yield, higher kernel/seed ratio, higher crude fat in seed while the other two traits showed no significant difference. This suggests that multiple generation mass selections can be additive in improvement.

\subsection{J. curcas Oil Composition Diversity}

Oil composition characters were also analyzed and compared in our study. These include fatty acid profile (reflected by relative composition of the four major fatty acids), the percentages of saturated and un-saturated fatty acids, as well as phosphorus and PE content (results summarized in Table 2).

J. curcas crude oil (JCO) comprises mostly ( $>98 \%$ ) triacyl glycerols (TAGs) of two saturated fatty acids (palmitic acid C16:0 and stearic acid C18:0) and 2 un-saturated fatty acids (oleic acid C18:1 and linoleic acid C18:2). The relative composition of these four fatty acids determines quality parameters of derived biodiesel. JO S2 population had the highest, while the TN population had the lowest palmitic acid content in oil. No significant difference was found among $\mathrm{CN}$, KE and AF populations for palmitic acid content, while $\mathrm{TN}, \mathrm{AF}$ and $\mathrm{CN}$ populations had significantly higher stearic acid content compared to other two populations. Adding palmitic acid and stearic acid together, high saturated fatty acid content was found in JO S2 and AF populations. For unsaturated fatty acids, the highest level of oleic acid (the main fatty acid component) was observed in TN population followed by JO S2 population. KE population had the lowest oleic acid content. The highest linoleic acid was observed in KE population followed by $\mathrm{CN}$ population. The TN population showed the lowest linoleic acid content $(32.74 \%)$. Due to the presence of two double bonds, linoleic acid is the main negative factor for oil oxidation stability.

The ratio of oleic and linoleic acid is considered a critical value in evaluating the quality of biodiesel feedstock. This value is very variable in plant oil due to both genetic and environmental reasons [21]. In our study, oleic/linoleic ratio ranged from 0.78 to 1.56 in tested JCO samples. Significantly, the highest value was found for TN population (1.40) followed by JO S2 (1.28), AF (1.24) and CN (1.23). The lowest oleic/linoleic ratio (1.09) was observed in KE population.

Based on fatty acid composition, we estimated the corresponding cetane number (which measures the ignition delay of a compression ignition fuel) and CFPP for FAME (or biodiesel). Among the five populations, the cetane number of KE FAME is the lowest (53.4) but still meets requirements of all quality specifications of biodiesel $(<=52)$. CFPP value ranged from -3.8 to $2{ }^{\circ} \mathrm{C}$ among all samples with the highest variation found within AF population. However, the difference among populations is less than $1{ }^{\circ} \mathrm{C}$. 
Table 2. Oil characteristics of the five $J$. curcas populations in Singapore.

\begin{tabular}{|c|c|c|c|c|c|c|c|c|c|c|}
\hline & \multicolumn{2}{|c|}{ JO S2 } & \multicolumn{2}{|c|}{$\mathbf{K E}$} & \multicolumn{2}{|c|}{$\mathrm{CN}$} & \multicolumn{2}{|c|}{$\mathbf{T N}$} & \multicolumn{2}{|c|}{$\mathbf{A F}$} \\
\hline & Mean & CV $(\%)$ & Mean & CV (\%) & Mean & CV $(\%)$ & Mean & CV (\%) & Mean & CV $(\%)$ \\
\hline \multicolumn{11}{|c|}{ Oil characteristics } \\
\hline Palmitic acid $(\%)$ & $15.39^{\mathrm{a}}$ & 3.12 & $14.85^{\mathrm{b}}$ & 4.25 & $14.85^{b}$ & 3.17 & $14.25^{\mathrm{c}}$ & 9.22 & $15.06^{\mathrm{b}}$ & 3.95 \\
\hline Stearic acid $(\%)$ & $6.87^{b}$ & 4.79 & $6.90^{b}$ & 6.36 & $7.16^{\mathrm{ab}}$ & 5.44 & $7.32^{\mathrm{a}}$ & 8.73 & $7.39^{\mathrm{a}}$ & 7.97 \\
\hline Oleic acid (\%) & $43.59^{b}$ & 2.18 & $40.56^{\mathrm{d}}$ & 5.48 & $42.18^{c}$ & 4.13 & $45.67^{\mathrm{a}}$ & 3.77 & $42.78^{c}$ & 3.39 \\
\hline Linoleic acid (\%) & $34.12^{c}$ & 3.03 & $37.61^{\mathrm{a}}$ & 7.89 & $35.03^{b}$ & 3.81 & $32.74^{\mathrm{d}}$ & 5.23 & $34.68^{b c}$ & 5.28 \\
\hline Saturated fatty acid (\%) & $22.26^{\mathrm{a}}$ & 2.15 & $22.01^{\mathrm{b}}$ & 2.41 & $22.30^{\mathrm{ab}}$ & 2.86 & $21.57^{\mathrm{b}}$ & 6.1 & $22.45^{\mathrm{a}}$ & 3.71 \\
\hline Unsaturated fatty acid (\%) & $77.71^{\mathrm{b}}$ & 0.65 & $78.17^{\mathrm{a}}$ & 1.22 & $77.93^{\mathrm{ab}}$ & 0.72 & $78.40^{\mathrm{a}}$ & 1.64 & $77.47^{\mathrm{b}}$ & 1.14 \\
\hline Oleic/linoleic & $1.28^{\mathrm{b}}$ & 5.16 & $1.09^{\mathrm{c}}$ & 13.2 & $1.23^{\mathrm{b}}$ & 6.27 & $1.40^{\mathrm{a}}$ & 7.93 & $1.24^{\mathrm{b}}$ & 8.3 \\
\hline Phosphorus (ppm) & $339.40^{b c}$ & 28.6 & $455.54^{\mathrm{a}}$ & 20.2 & $398.00^{\mathrm{a}}$ & 9.6 & $376.6^{\mathrm{ab}}$ & 18.1 & $294.60^{\mathrm{c}}$ & 21 \\
\hline PE content in kernel $(\mathrm{mg} / \mathrm{g})$ & $1.4^{\mathrm{b}}$ & 29.2 & $1.92^{\mathrm{b}}$ & 27.1 & $0.76^{\mathrm{c}}$ & 37.1 & $4.6^{\mathrm{a}}$ & 40 & $1.48^{b}$ & 53.6 \\
\hline \multicolumn{11}{|c|}{ Estimation of the physical properties of fatty acid methyl esters } \\
\hline Predicted cetane number & $54.2^{\mathrm{a}}$ & 0.46 & $53.4^{b}$ & 1.4 & $54.0^{\mathrm{a}}$ & 0.6 & $54.4^{\mathrm{a}}$ & 0.9 & $54.1^{\mathrm{a}}$ & 0.9 \\
\hline Predicted CFPP $\left({ }^{\circ} \mathrm{C}\right)$ & $-0.83^{b}$ & 57.9 & $-0.9^{b}$ & 84.7 & $-0.54^{\mathrm{ab}}$ & 110 & $-0.50^{\mathrm{ab}}$ & 206.7 & $-0.1^{\text {a }}$ & 92.9 \\
\hline
\end{tabular}

Populations were from Africa (AF), China (CN), India (TN), Indonesia (KE) and the improved variety, JO S2, CV(\%), coefficient of variance (\%); Tukey’s (HSD)

comparison ranking $(p<0.05)$ : $\mathrm{a}>\mathrm{b}>\mathrm{c}$; PE, phorbol ester; CFPP, cold filter plugging point. 
Considerably higher variation was found for phosphorus content among populations, and the phosphorus content in JCO varied from $157 \mathrm{ppm}$ to $756 \mathrm{ppm}$ among all samples. AF population showed the lowest phosphorus content (294.60 ppm), while higher phosphorus content was observed in KE and CN populations (455 and $398 \mathrm{ppm}$ ). In our investigation, PE content ranged from 0.36 to $11.36 \mathrm{mg} \mathrm{g}^{-1} \mathrm{kernel}$ at plant level, as many as 27 times of difference between the highest and the lowest. Indian population showed the highest average PE content $\left(4.6 \mathrm{mg} \mathrm{g}^{-1} \mathrm{kernel}\right)$ whereas the lowest content of PE was observed in Chinese population $\left(0.76 \mathrm{mg} \mathrm{g}^{-1} \mathrm{kernel}\right)$. AF, JO S2 and KE populations had moderate PE content. High level of within-population variation was also found in all five populations.

\subsection{Morphological Characters of JO S2 in Singapore}

JO S2 has typical 5 to 7 undulation lobed leaves with a length and width of 18 and $23 \mathrm{~cm}$. The leaf color is green. Leaves are alternate to sub opposite with a 1st-9th-17th spiral phyllotaxis on the trunk. The trunk of JO S2 is strong and the branches are hard. The angles between primary branches and the tree trunk are between 30 and 50 degrees. The plant height is about $1.2-1.5 \mathrm{~m}$ at the end of the first year, which is significant shorter than that of AF, CN, and TN (Table 3). The diameter of the canopy is about $0.95-1.2 \mathrm{~m}$ at the end of the first year, which is not significant different from other populations. The plant height reached up to $2 \mathrm{~m}$, and the canopy spread up to $2.2 \mathrm{~m}$ at the end of the second year for un-pruned plants $(2 \mathrm{~m} \times 2 \mathrm{~m}$ spacing).

Table 3. Morphological traits of the five populations in the Singapore trial at the end of the first year.

\begin{tabular}{|c|c|c|c|c|c|c|c|}
\hline Populations & Height (cm) & Canopy (cm) & $\begin{array}{c}\text { No. of Primary } \\
\text { Branches }\end{array}$ & $\begin{array}{c}\text { Days to } \\
\text { Flowering }\end{array}$ & $\begin{array}{c}\text { No. of } \\
\text { Females }\end{array}$ & $\mathbf{M} / \mathbf{F}$ & $\begin{array}{c}\text { Interval } \\
\text { Days }\end{array}$ \\
\hline $\mathrm{AF}$ & $183.4^{\mathrm{a}}$ & 184.2 & $1.48^{\mathrm{c}}$ & $176.5^{\mathrm{a}}$ & $8.2^{\mathrm{c}}$ & $23.7^{b}$ & 19.7 \\
\hline $\mathrm{CN}$ & $167.6^{b}$ & 189.6 & $2.29^{b}$ & $180.7^{\mathrm{a}}$ & $7.3^{\mathrm{c}}$ & $28.8^{a}$ & 21 \\
\hline JO S2 & $135.3^{c}$ & 202.1 & $3.25^{\mathrm{a}}$ & $142.5^{b}$ & $10.8^{b}$ & $14.6^{\mathrm{c}}$ & 20.8 \\
\hline $\mathrm{KE}$ & $133.0^{\mathrm{c}}$ & 190.1 & $3.00^{\mathrm{a}}$ & $146.9^{b}$ & $12.6^{\mathrm{a}}$ & $30.2^{\mathrm{a}}$ & 22 \\
\hline $\mathrm{TN}$ & $168.5^{b}$ & 194.4 & $2.29^{b}$ & $180.6^{\mathrm{a}}$ & $8.2^{\mathrm{c}}$ & $24.4^{b}$ & 19.6 \\
\hline
\end{tabular}

Tukey's (HSD) comparison ranking $(p<0.05)$ : a $>\mathrm{b}>\mathrm{c} . \mathrm{M} / \mathrm{F}$, male to female flower ratio.

JO S2 is an early flowering $J$. curcas variety, with an average first flowering date of $143 \mathrm{~d}$ after seed sowing. By comparison, accessions from Africa (AF), India (TN) and China (CN) flowered $34 \mathrm{~d}$, $38 \mathrm{~d}$, and $38 \mathrm{~d}$ later than JO S2, respectively. KE flowered $4 \mathrm{~d}$ later than JO S2 (Table 3). First flower bunch formed on the top of the tree trunk terminates the growth of the trunk. It takes about $20 \mathrm{~d}$ from budding to flowering, during which two to three top-branches emerge below the terminal flower bunch (50-60 degree between each other). Each top-branch will continuously form new branches dichotomously 4-5 times; resulting with 10-12 flower bunches with the interval of 18-21 d between 2 adjacent flower bunches (Interval Days). Three to six primary lateral-branches (primary branch) will emerge on the trunk at the time or after the 1st flower bunch emergence. Number of primary branches of JO S2 is significantly more than those of AF, CN and TN (Table 3). Most of the lateral-branches will proceed to flowering and fruiting. JO S2 is high on lateral-branch formation. Percentage of 
effective branch (flowering branch) is higher than $90 \%$ for the first year. Dormancy of meristem during dry spell is less than $5 \%$.

Total number of flower bunches of JO S2 ranges from 60 to 100 for the first year and 140 to 180 new ones for the second year per un-pruned plant. JO S2 has moderate flower bunch at average 10.8 female flowers per flower bunch with male to female flower $(\mathrm{M} / \mathrm{F})$ ratio is around 14.6. The female flower numbers per bunch is significant more than that of $\mathrm{AF}, \mathrm{CN}$ and $\mathrm{TN}$, but less than that of $\mathrm{KE}$; while its $\mathrm{M} / \mathrm{F}$ ratio is significantly lower than all other populations (Table 3 ). Within the same flower bunch, all female flowers open within 2-3 d and all male flowers open within 5-10 d.

\subsection{JO S2 Performance in India}

In both Indian sites, JO S2 exhibited better self-branching and started flowering within 3 mth of planting ( $\sim 150 \mathrm{~d}$ after seed sowing). The first fruit harvesting started from 5 th month onwards. In the first year, the plant height of JO S2 was about $2 \mathrm{~m}$ and the canopies were $1.9 \mathrm{~m}$ and $2.0 \mathrm{~m}$ for data collection plants; while Indian variety was $2.78 \mathrm{~m}$ in height and $2.2 \mathrm{~m}$ canopy, which was taller and wider than JO S2. The average numbers of primary branches per plant of JO S2 were 3.92 in Coimbatore and 4.2 in Madurai; the averages for fruits per bunch were 6.6 and 8.5 and those for fruit bunches per plant were 102.8 and 117.7 (Table 4) and accumulative seed yield was $955 \mathrm{~g}$ and $982 \mathrm{~g}$ per plant. While Indian variety had an average of 3.5 primary branches, 6.9 fruits per bunch, 35.5 fruit bunches per plant, and seed yield was only $278 \mathrm{~g}$ per plant, significantly lower than that of JO S2. First year seed yield of $>900 \mathrm{~g} \mathrm{plant}^{-1}\left(>2 \mathrm{t} \mathrm{ha}^{-1}\right)$ is a record that is not reported anywhere. Good productivity for the first year will give farmers early return and more confidence in adopting Jatropha plantation. It is a significant advantage for this perennial energy plant.

In the second year, limited canopy expansion was observed because of canopy overlapping among plants. Plant height also didn't increase much since branches were drooping down due to heavy fruiting. The number of primary branches at Coimbatore site increased to 5.5, but at Madurai site remained the same. The number of fruit bunches per plant increased at both sites, but the fruit number per bunch reduced in both sites, especially at Madurai site from 8.53 declined to 4.31. The main reason for this distinct reduction in fruit number per bunch might be the longer dry spell at Madurai site and less irrigation than the first year. Accumulated seed yield in the second year increased to as much as $1721 \mathrm{~g}$ per plant in Coimbatore site and 1,146 g per plant at Madurai site. In comparison, the local Indian variety had much fewer fruit bunches (81.6), fruits per bunch (3.91) and much lower seed yield per plant $(403.5 \mathrm{~g})$. The actual population seed yield per hectare of JO S2 was 2.33 and $2.95 \mathrm{t} \mathrm{ha}^{-1}$ in the first year; and reached 4.25 and $3.13 \mathrm{t} \mathrm{ha}^{-1}$ in the second year. Seed yield of the control variety still lagged far behind JO S2 (403 g vs $1721 \mathrm{~g}$ ) although they grew in the same climate and subjected to the same agronomic treatments. Better seed productivity of JO S2 than the locally available variety is clear and significant. Our best second yield of $1.72 \mathrm{~kg}$ per plant $\left(4.25 \mathrm{t} \mathrm{ha}^{-1}\right)$ set a record in India, better than all reported for wild Jatropha accessions [6-10]. We attribute this higher productivity mostly to improvement of genetics. This suggestion is supported by the much poorer productivity of the local control variety/accession under the same growth conditions and agronomic practices. The much better seed productivity of JO S2 clearly demonstrates that Jatropha seed productivity potential is achievable through combination of improved genetics, suitable climate and good agronomic practices. We expect 
the seed yield will increase further before stabilized in year 4 or 5 . With an estimated mature yield of more than $5 \mathrm{t} \mathrm{ha}^{-1}$, JO S2 holds good promise to be commercially viable for large scale plantation.

Table 4. JO S2 performance in two sites in Southern India for two years.

\begin{tabular}{|c|c|c|c|c|c|c|c|c|c|c|}
\hline \multirow{3}{*}{ Parameters } & \multicolumn{6}{|c|}{ Coimbatore } & \multirow{2}{*}{\multicolumn{4}{|c|}{$\begin{array}{c}\text { Madurai } \\
\text { JO S2 } \\
\end{array}$}} \\
\hline & \multicolumn{4}{|c|}{ JO S2 } & \multicolumn{2}{|c|}{ Local } & & & & \\
\hline & Year 1 & $\begin{array}{l}\text { CV } \\
(\%)\end{array}$ & Year 2 & $\begin{array}{l}\text { CV } \\
(\%)\end{array}$ & Year 1 & Year 2 & Year 1 & $\begin{array}{l}\text { CV } \\
(\%)\end{array}$ & Year 2 & $\begin{array}{l}\text { CV } \\
(\%)\end{array}$ \\
\hline Plant height $(\mathrm{cm})$ & 202.9 & 7.0 & 228.6 & 12.2 & 278.0 & - & 198.6 & 5.8 & 237.7 & 11.2 \\
\hline Canopy $(\mathrm{cm})$ & 190.45 & 3.5 & 213.0 & 10.7 & 221.5 & - & 203.6 & 13.7 & 246.1 & 15.2 \\
\hline $\begin{array}{l}\text { No. of primary } \\
\text { branches per plant }\end{array}$ & 3.9 & 14.9 & 5.5 & 18.2 & 3.5 & 4.2 & 4.2 & 18.0 & 4.2 & 13.0 \\
\hline $\begin{array}{l}\text { No. of flower } \\
\text { bunches per plant }\end{array}$ & 166.1 & 13.0 & 223.5 & 7.9 & 103.0 & 132.8 & 159.1 & 10.4 & 304.3 & 12.5 \\
\hline $\begin{array}{l}\text { No. of fruit bunches } \\
\text { per plant }\end{array}$ & 102.8 & 8.6 & 174.8 & 7.1 & 35.5 & 81.6 & 117.7 & 12.1 & 240.6 & 6.4 \\
\hline $\begin{array}{l}\text { Average No. of fruit } \\
\text { per bunch }\end{array}$ & 6.6 & 5.8 & 6.0 & 6.3 & 6.9 & 3.9 & 8.5 & 9.6 & 4.3 & 8.3 \\
\hline $\begin{array}{l}\text { Total No. of fruit } \\
\text { per plant }\end{array}$ & 801 & 8.7 & 1251.7 & 5.6 & 269.0 & 311.3 & 1002.7 & 6.6 & 872.2 & 12.7 \\
\hline $\begin{array}{l}\text { Seed yield per plant } \\
\text { (g) (labelled plants) }\end{array}$ & 955 & 9.3 & $1,721.3$ & 5.4 & 277.9 & 403.5 & 982.2 & 15.4 & 1146.6 & 15.9 \\
\hline $\begin{array}{l}\text { Number of plants } \\
\text { (population) }\end{array}$ & $>1000$ & & $>1000$ & & & & $>1000$ & & $>1000$ & \\
\hline $\begin{array}{l}\text { Actual seed yield per } \\
\text { plant }(\mathrm{g})\end{array}$ & 1180.0 & - & 1699.0 & - & 208.0 & 375.0 & 933.6 & - & 1252.3 & - \\
\hline
\end{tabular}

The crude oil content in seed of JO S2 was $27.35 \%$, while the crude oil content in seed of local Indian variety was $25.63 \%$. The average number is quite consistent with the result in Singapore trial $(28.8 \%)$.

JO S2 plants in India were visibly uniform in the field, which was quantitatively supported by the narrow deviations $(\mathrm{CV}<16 \%)$ from the average values for all traits studied. The uniform flowering and fruiting traits (number of flower bunches per plant, number of fruit bunches per plant, number of fruits per plant, per plant seed yield) also explain the high level of correlation between the average value of labeled plant and average value of actual harvest of the total population. This is a clear indication of the improvement of $J$. curcas in field uniformity.

Between Singapore and the two trial sites in Southern India, while the temperature is not much different, there are differences in the annual precipitation $(2500 \mathrm{~mm}$ vs $600-800 \mathrm{~mm})$, rainfall distribution (throughout the year vs mostly in monsoon seasons in Sept.-Nov.), soil type (clay vs sandy loam, acidic $v s$ alkaline), fertility (poor vs better) and some variations in agronomic practices. Despite these differences, most agronomic traits of JO S2 in Southern India were consistent with those in Singapore including early flowering, good self-branching, plant architecture, fruit bunch characters, 100 -seed weight, and crude oil content. For those traits influenced more by environmental factors, such as the plant height, canopy, and accumulated seed yield, they were quite similar in the three sites of 
two different climatic conditions. These results demonstrate that JO S2 has wide environmental adaptation. Further agronomic trials (fertilizer application trial, pruning trial, irrigation trial, and planting density trial et al.) are being conducted in India to optimize plantation management practices to maximize seed yield of JO S2 and other JOil varieties.

JO S2, one of the varieties released by JOil, was developed by use of systematic mass selection method from limited $J$. curcas accessions. Agronomic trait variations among accessions as well as among individual plants within an accession were discovered through field trials. These diversities were confirmed by replicated field trials conducted in the same year and/or different years. Some important agronomic traits, such as early flowering, better natural branching pattern, better flower/fruit bunch characters, 100 seed weight, and crude oil content etc. were found with high heritability. Plus trees $(5 \%-10 \%$ of population) were selected based on these important traits and accumulated seed yield. Open pollinated seeds from plus trees were harvested and evaluated on individual mother plant basis (plant row) in the next generation. Plus individual trees or elite plant rows were further chosen for seed harvest. An improved population is confirmed through comparison with accessions in field trials. New breeding approaches are implemented in JOil with inter-species hybridization and advance backcross breeding strategy, aiming at introgression of favorable exogenous traits, increase genetic diversities, and creation of unique germplasm. JO S2 is now used as the control variety in field trials of new hybrid populations. Plus plants with interesting traits or better accumulated seed yield are chosen for further evaluation. Those hybrids with better performance are propagated through tissue culture for conducting multi-location trials before commercial launch. It is a new breeding strategy for direct utilization of hybrid vigor derived from distant hybridizations.

\section{Conclusions}

In summary, J. curcas accessions exhibited big variations in seed productivity and various seed traits even under the same agronomic practices and climate conditions and there is the lack of uniformity within population, hence not suitable for commercial plantation. We demonstrate in this paper that mass selection of open pollinated populations can be effective in quick improvement of seed yield and field uniformity. The improved variety JO S2 can perform well in two different climate conditions, suggesting that it has wider adaptability and will be useful for establishing large scale plantation.

\section{Acknowledgments}

We thank Singapore Economic Development Board (EDB) for the Research Incentive Scheme for Companies (RISC) grant. Some part of the work was supported by JOil TLL Jatropha Biotechnology Program.

\section{Author Contributions}

Yan Hong designed the project, supervised most activities, conducted statistical analysis and prepared the manuscript; Chengxin Yi conducted the breeding; coordinated the field trial in Singapore and participated in the India field trials and prepared the manuscript; Chalapathy Reddy coordinated the Indian field trials and data collection; Kins Varghese participated in the Indian trial and data collection; Shilu Zhang participated in the Singapore field trial and data collection; Manju Kallath and 
Binoy Kunjachen participated in the India field trials; Thi Ngoc Ha Bui did most phytochemical analysis and conducted statistical analysis; Srinivasan Ramachandran provided support and some supervision for the Indian trials.

\section{Conflicts of Interest}

JOil (S) is a company dedicated to improvement of Jatropha for commercial plantation.

\section{References}

1. Divakara, B.N.; Upadhyaya, H.D.; Wani, S.P.; Gowda, C.L.L. Biology and genetic improvement of Jatropha curcas L.: A review. Appl. Energy 2010, 87, 732-742.

2. Heller, J. Physic nut, Jatropha curcas; International Plant Genetic Resources Institute: Rome, Italy, 1996.

3. Gopinathan, M.; Sudhakaran, R. Biofuels: opportunities and challenges in India. In Vitro Cell. Dev. Biol.-Plant 2009, 45, 350-371.

4. Singh, K.; Singh, B.; Verma, S.K.; Patra, D.D. Jatropha curcas: A ten year story from hope to despair. Renew. Sustain. Energ. Rev. 2014, 35, 356-360.

5. Baker, P.; Ebrahim, Z. Jatropha-an Update; CABI-UK: Wallingford, UK, 2012.

6. Terren, M.; Saverys, S.; Jacquet de Haveskercke, P.; Winandy, S.; Mergeai, G. Attempted Cultivated of Jatropha curcas L. in the Lower Senegal river Valley: Story of a Failure. Tropicultura 2012, 4, 204-208.

7. Everson, C.S.; Mengistu, M.G.; Gush, M.B. A field assessment of the agronomic performance and water use of Jatropha curcas in South Africa. Biomass Bioenerg. 2013, 59, 59-69.

8. Tikkoo, A.; Yadav, S.S.; Kaushik, N. Effect of irrigation, nitrogen and potassium on seed yield and oil content of Jatropha curcas in coarse textured soils of northwest India. Soil Tillage Res. 2013, 134, 142-146.

9. Rao, G.R.; Korwar, G.R.; Shanker, A.K.; Ramakrishna, Y.S. Genetic association, variability and diversity in seed characters, growth, reproductive phenology and yield in Jatropha curcas (L) accessions. Trees 2008, 22, 697-609.

10. Singh, B.; Singh, K.; Rejeshwar Rao, G.; Chikara, J.; Kumar, D.; Mishra, D.K.; Saikia, S.P.; Pathre, U.V.; Raghuvanshi, N.; Rahi, T.S.; et al. Agro-technology of Jatropha curcas for diverse environmental conditions in India. Biomass Bioenerg. 2013, 48, 191-202.

11. Kaushik, N.; Krishan, K.; Sushil, K.; Kaushik, N.; Roy, S. Genetic variability and divergence studies in seed traits and oil content of Jatropha (Jatropha curcas L.) accessions. Biomass Bioenerg. 2007, 31, 497-502.

12. Basha, S.D.; Francis, G.; Makkar, H.P.S.; Becker, K.; Sujatha, M. A comparative study of biochemical traits and molecular markers for assessment of genetic relationships between Jatropha curcas L. germplasm from different countries. Plant Sci. 2009, 176, 812-823.

13. Yi, C.; Zhang, S.; Liu, X.; Bui, H.T.; Hong, Y. Does epigenetic polymorphism contribute to phenotypic variances in Jatropha curcas L? BMC Plant Biol. 2010, 10, 259. 
14. Makkar, H.P.S.; Becker, K.; Sporer, F.; Wink, M. Studies on Nutritive Potential and Toxic Constituents of Different Provenances of Jatropha curcas. J. Agric. Food Chem. 1997, 45, 3152-3157.

15. Abou Kheira, A.A.; Atta, N.M.M. Response of Jatropha curcas L. to water deficits: Yield, water use efficiency and oilseed characteristics. Biomass Bioenerg. 2009, 33, 1343-1350.

16. Carrels, N. Jatropha curcas: A review. Adv. Bot. Res. 2009, 50, 39-76.

17. Rao, K.; Chakrabarti, P.; Rao, B.V.S.K.; Prasad, R.B.N. Phospholipid Composition of Jatropha curcus Seed Lipids. J. Am. Oil Chem. Soc. 2009, 86, 197-200.

18. Yunping, B.; Ha, B.T.; Eunice, Y.; Chueng, L.L.; Yan, H. Light induced degradation of phorbol esters. Ecotoxicol. Environ. Saf. 2012, 84, 268-273.

19. Bamgloye, A.I.; Hansen, A.C. Prediction of cetane number of biodiesel fuel from the fatty acid methyl ester (FAME) composition. Int. Agrophysic 2008, 22, 21-29.

20. Ramos, M.J.; Fernández, C.M.; Casas, A.; Rodriguez, L.; Perez, A. Influence of fatty acid composition of raw materials on biodiesel properties. Bioresour. Technol. 2009, 100, 261-268.

21. Ghulam, Q.; Shahbaz, A.; Fayyaz, U.H.; Mumtaz, A.C. Oil and fatty acid accumulation in sunflower as influenced by temperature variation. Pak. J. Bot. 2006, 38, 1137-1147.

(C) 2014 by the authors; licensee MDPI, Basel, Switzerland. This article is an open access article distributed under the terms and conditions of the Creative Commons Attribution license (http://creativecommons.org/licenses/by/3.0/). 